\title{
Stabilization and Crystal Characterization of Electric Arc Furnace Oxidizing Slag Modified with Ladle Furnace Slag and Alumina
}

\author{
Chia-Chun Li, Chi-Ming Lin, Yu-En Chang, Wei-Ti Chang and Weite Wu * \\ Department of Materials Science and Engineering, National Chung Hsing University, 145 Xingda Rd., \\ South Dist., Taichung City 40227, Taiwan; r101066042@smail.nchu.edu.tw (C.-C.L.); \\ lingiminboy@yahoo.com.tw (C.-M.L.); wd06071203@gmail.com (Y.-E.C.); e08094661234@gmail.com (W.-T.C.) \\ * Correspondence: wwu@nchu.edu.tw; Tel.: +886-4-2284-0500 (ext. 604)
}

Received: 9 March 2020; Accepted: 10 April 2020; Published: 11 April 2020

\begin{abstract}
Ladle furnace slag (LFS) is a by-product of a steel plant. As the chemical composition and free lime (f-CaO) content of each batch of slag are significantly different, it is difficult to use the same operation method to recover LFS. In this study, three types of LFS were used to partially replace lime in the dephosphorization process, and the compositions were adjusted to a fixed range by adding $\mathrm{Al}_{2} \mathrm{O}_{3}$. This method reduced the effect of different LFS components and significantly reduced the $\mathrm{Ca}_{2} \mathrm{SiO}_{4}$ amount (from $31.4 \%$ to $17.1 \%$ ) in the produced modified oxidizing slag. Furthermore, after dephosphorization, the X-ray diffraction (XRD) patterns of the three LFSs indicated transformation into gehlenite and wustite. The modified oxidizing slag $\mathrm{f}-\mathrm{CaO}$ content was $0.41 \%$, which was lower than that in the electric arc furnace oxidizing slag (1.2-1.4\%) and the LFS (0.9-3.4\%). In addition, the expansion test results of the modified oxidizing slag showed almost no expansion, which conforms to the ASTM D2940 standards; thus, this material can be used for preparing paving materials. This study provides an approach for LFS treatment that could reduce costs within the steel industry.
\end{abstract}

Keywords: gehlenite; $\mathrm{Ca}_{2} \mathrm{SiO}_{4} ; \mathrm{f}-\mathrm{CaO}$; volume expansion; dephosphorization; Image-Pro-Plus

\section{Introduction}

The electric arc furnace oxidizing slag (EAFS) and ladle furnace slag (LFS) are by-products of a metallurgical process. LFS is produced in the final stages of steelmaking and is composed of over $50 \% \mathrm{CaO}$ and $\mathrm{MgO}$ by weight. Free lime (f-CaO) is produced in LFS as a result of undissolved $\mathrm{CaO}$ solids, which affect LFS volumetric instability. The dissociation of dicalcium silicate $\left(\beta-\mathrm{Ca}_{2} \mathrm{SiO}_{4}, \mathrm{C}_{2} \mathrm{~S}\right)$ and tricalcium silicate $\left(\mathrm{Ca}_{3} \mathrm{SiO}_{5}, \mathrm{C}_{3} \mathrm{~S}\right)$ produces $\mathrm{f}-\mathrm{CaO}$ hydrate in a short period and causes expansion [1-4]. Generally, in a steel plant, aging methods are used to treat slag [5]. In this method, the slag is crushed into an appropriate particle size and stacked in an open field to convert $\mathrm{CaO}$ into $\mathrm{Ca}(\mathrm{OH})_{2}$ through hydration. However, at least three months are required to reduce the $\mathrm{f}-\mathrm{CaO}$ content in the slag to achieve stability, and the higher the $\mathrm{f}-\mathrm{CaO}$ content, the longer is the duration needed for stabilization. This also increases the costs of a steel plant. Different operation practices in a steel plant may substantially affect the chemical composition of the slag [1]. In addition, the f-CaO content of LFS in each batch differs, making it difficult to recycle LFS with different components as fixed materials or supplements. LFS has a low recovery potential because of the fine LFS particles and unfavorable leaching performance with water (a pH of between 11.7 and 12.8) [6]; therefore, about $80 \%$ of LFS produced in the European Union is landfilled [6,7].

The steel industry produces a large amount of solid LFS every year. Taiwan production of LFS is estimated at around 460 thousand tons (total production of crude steel multiplied by $0.02 \%$ ) [8], so its final disposal is an important issue and has prompted researchers to seek alternative methods for slag reuse. 
Several studies have explored the characteristics of LFS and potential solutions for LFS reuse [3,9-14]. There are two methods of recycling LFS. The first is to use steel slag as a raw material to prepare cement clinker because slag mineral composition includes $\mathrm{C}_{3} \mathrm{~S}, \mathrm{C}_{2} \mathrm{~S}$, tetracalcium aluminoferrite $\left(\mathrm{C}_{4} \mathrm{AF}\right)$, and dicalcium ferrite $\left(C_{2} F\right)$, which show cementitious properties when mixed with water [15-18]. However, the effect of different $\mathrm{f}-\mathrm{CaO}$ contents on cement, the proportion of LFS in the cement, and the limitations due to various regulations are problems hindering practical applications. The second method is to use LFS to partially replace lime in a metallurgical process, given that approximately $50 \%$ of LFS is CaO by weight $[19,20]$. In Taiwan, the estimated volume of lime used in steel is 920 thousand tons. The amount of lime used is greater than the production of LFS. This approach has the potential to effectively reuse LFS. However, as mentioned previously, significant differences in LFS compositions affect the stability of the metallurgical process in a steel plant. Therefore, the application described above has not been widely used in Taiwan.

EAFS has good physical and mechanical properties [21,22], and it is easier to treat and recycle than LFS. EAFS can be used in the road base layers and the hot asphalt mixtures $[23,24]$. However, several researchers $[25,26]$ have shown that the typical hydrated phase (such as portlandite and calcium silicate) in EAFS releases toxic elements such as $\mathrm{Ba}, \mathrm{Cr}$, and $\mathrm{V}$. These hydrated phases may increase the risk of expansion or degradation. However, some studies [26,27] have indicated that gehlenite $\left(\mathrm{Ca}_{2} \mathrm{Al}_{2} \mathrm{SiO}_{7}\right)$ has non-hydraulic properties, and that increasing the gehlenite phase content in the slag can improve slag stability.

Lime can react with phosphorus in the dephosphorization process in electric furnaces, thus playing an important role in the process. LFS has a low melting point of around $1400-1500{ }^{\circ} \mathrm{C}[28,29]$. This can accelerate slag liquefaction during dephosphorization. The chemical reactions involved in dephosphorization are as follows:

$$
\begin{aligned}
2[\mathrm{P}]+5[\mathrm{O}] & =\left(\mathrm{P}_{2} \mathrm{O}_{5}\right), \\
{[\mathrm{Fe}]+[\mathrm{O}] } & =(\mathrm{FeO}) \\
2[\mathrm{P}]+5(\mathrm{FeO})+3(\mathrm{CaO}) & =\left(3 \mathrm{CaO} \cdot \mathrm{P}_{2} \mathrm{O}_{5}\right)+5[\mathrm{Fe}],
\end{aligned}
$$

where [] corresponds to molten iron and () corresponds to the slag. As oxygen is injected into the bath (molten steel), $\mathrm{FeO}$ and $\mathrm{P}_{2} \mathrm{O}_{5}$ are formed and float up to the slag layer. Then, $3 \mathrm{CaO} \cdot \mathrm{P}_{2} \mathrm{O}_{5}$ precipitates in the oxidizing slag. Finally, $3 \mathrm{CaO} \cdot \mathrm{P}_{2} \mathrm{O}_{5}$ forms a stable $\mathrm{Ca}_{3} \mathrm{P}_{2} \mathrm{O}_{8} \cdot \mathrm{Ca}_{2} \mathrm{SiO}_{4}$ solid solution with $\mathrm{C}_{2} \mathrm{~S}$ [27]. At this point, adding a certain amount of $\mathrm{Al}_{2} \mathrm{O}_{3}$ into the oxidizing slag can effectively reduce the amount of $\mathrm{C}_{2} \mathrm{~S}$ and form $\mathrm{Ca}_{2} \mathrm{Al}_{2} \mathrm{SiO}_{7}$, as shown in the following equation [30]:

$$
\mathrm{Ca}_{3} \mathrm{P}_{2} \mathrm{O}_{8} \cdot \mathrm{yCa}_{2} \mathrm{SiO}_{4}+\mathrm{x}\left(\mathrm{Al}_{2} \mathrm{O}_{3}\right)=x \mathrm{Ca}_{2} \mathrm{Al}_{2} \mathrm{SiO}_{7}+\mathrm{Ca}_{3} \mathrm{P}_{2} \mathrm{O}_{8} \cdot(\mathrm{y}-\mathrm{x}) \mathrm{Ca}_{2} \mathrm{SiO}_{4},
$$

In this study, the methods that enable LFS to be used as a renewable material in dephosphorization were evaluated. Different types of LFS were employed in the induction furnace to simulate the electric arc furnace (EAF) primary refining process (dephosphorization), and $\mathrm{Al}_{2} \mathrm{O}_{3}$ was added to adjust the composition to a fixed range in the dephosphorization process. This improved stability and reduced the influence of the differences in LFS compositions. Moreover, LFS can be transformed into modified oxidizing slag during dephosphorization. The amount of the hydrated phase $\left(C_{2} S\right)$ in the EAFS was reduced as much as possible, and the final modified oxidizing slag was transformed into a non-hydraulic phase $\left(\mathrm{Ca}_{2} \mathrm{Al}_{2} \mathrm{SiO}_{7}\right)$ with low $\mathrm{f}-\mathrm{CaO}$ content and low volume expansion. Please note that the composition of the modified oxidizing slag after dephosphorization is similar to that of EAFS (20-45\% T-Fe), so the modified oxidizing slag is defined as a modification of EAFS in this study.

\section{Materials and Methods}

\subsection{Slag Sampling and Characterization}

The slag samples used in this study were supplied by ten different steel plants to understand the current composition of slag. The chemical compositions of the slags were analyzed by wavelength 
dispersive X-ray fluorescence (WDXRF) spectroscopy (Supermini 200, Rigaku Corp., Tokyo, Japan) and are listed in Table 1. The major LFS oxides are $\mathrm{CaO}$ (40-56 wt.\%), $\mathrm{Al}_{2} \mathrm{O}_{3}$ (3-29 wt.\%), $\mathrm{SiO}_{2}$ (5-27 wt.\%), and $\mathrm{MgO}$ (4-18 wt.\%). The LFS samples could be divided into three types: (1) a high $\mathrm{SiO}_{2}$ content (19-27 wt.\%), (2) a high $\mathrm{Al}_{2} \mathrm{O}_{3}$ content (19-29 wt.\%), and (3) a high MgO content (13-18 wt.\%). The method to distinguish between LFS and EAFS is the T-Fe content of EAFS (20-45\% T-Fe). Because the composition of the modified oxidizing slag is similar to that of EAFS, EAFS will be used as a control group to compare with the modified oxidizing slag.

Table 1. Compositions of LFS and EAFS as determined by WDXRF spectroscopy. Types of LFS: (1) a high $\mathrm{SiO}_{2}$ content, (2) a high $\mathrm{Al}_{2} \mathrm{O}_{3}$ content, and (3) a high $\mathrm{MgO}$ content.

\begin{tabular}{ccccccccc}
\hline \multirow{2}{*}{ Specimen } & \multirow{2}{*}{ Types } & \multicolumn{7}{c}{ Chemical Composition (wt.\%) } \\
\cline { 3 - 8 } & & $\mathbf{C a O}$ & $\mathbf{S i O}_{\mathbf{2}}$ & $\mathbf{A l}_{\mathbf{2}} \mathbf{O}_{\mathbf{3}}$ & $\mathbf{M g O}$ & $\mathbf{T}-\mathbf{F e}$ & $\mathbf{M n O}$ & $\mathbf{S}$ \\
\hline LFS 1 & $(1)$ & 45.9 & 21.6 & 4.2 & 8.6 & 1.8 & 0.3 & 0.867 \\
LFS 2 & $(2)$ & 50.2 & 11.7 & 19.9 & 4.9 & 2.1 & 0.3 & 0.727 \\
LFS 3 & $(3)$ & 44.1 & 17.5 & 3.4 & 17.9 & 2.3 & 0.6 & 0.567 \\
LFS 4 & $(1)$ & 55.4 & 27.2 & 2.7 & 5.8 & 1.5 & 0.4 & 0.547 \\
LFS 5 & $(1)$ & 52.1 & 19.3 & 14.8 & 4.9 & 0.7 & 0.1 & 0.994 \\
LFS 6 & $(2)$ & 52.3 & 5.1 & 28.9 & 5.4 & 0.5 & 0.1 & 0.911 \\
LFS 7 & $(1)$ & 46.4 & 21.1 & 3.9 & 7.0 & 1.6 & 0.5 & 0.772 \\
LFS 8 & $(1)$ & 52.6 & 23.6 & 4.2 & 8.8 & 0.3 & 0.2 & 0.828 \\
LFS 9 & $(3)$ & 40.3 & 15.9 & 4.8 & 13.1 & 4.5 & 0.6 & 0.542 \\
LFS 10 & $(1)$ & 47.7 & 21.8 & 4.3 & 10.4 & 2.2 & 0.7 & 0.690 \\
EAFS 1 & & 37.8 & 11.2 & 7.4 & 6.2 & 25.9 & 3.4 & 0.102 \\
EAFS 2 & & 28.8 & 11.9 & 6.4 & 3.7 & 28.6 & 4.9 & 0.241 \\
EAFS 3 & & 35.6 & 10.7 & 4.5 & 6.9 & 28.4 & 4.5 & 0.097 \\
\hline
\end{tabular}

The phase diagram of the $\mathrm{CaO}-\mathrm{FeO}-\mathrm{SiO}_{2}-\mathrm{Al}_{2} \mathrm{O}_{3}$ system of the analyzed slags is shown in Figure 1 [31]. In Figure 1, the three regions are marked as 1,2 , and 3 . The path of the slag in the experiment was $1 \rightarrow 2 \rightarrow 3$. Region 1 corresponds to LFS obtained by LF refining (desulfurization), and the major phases are $\mathrm{Ca}_{2} \mathrm{SiO}_{4}$ $\left(\mathrm{C}_{2} \mathrm{~S}\right), \mathrm{Ca}_{3} \mathrm{SiO}_{5}\left(\mathrm{C}_{3} \mathrm{~S}\right)$, and $\mathrm{CaO}$. Region 2 corresponds to the EAFS obtained by EAF primary refining (dephosphorization), and the major phases are $\mathrm{C}_{2} \mathrm{~S}$ and wustite (FeO). Region 3 corresponds to the region expected to be modified by the experiment, and the major phases are gehlenite $\left(\mathrm{C}_{2} \mathrm{Al}_{2} \mathrm{SiO}_{7}\right)$ and $\mathrm{FeO}$.

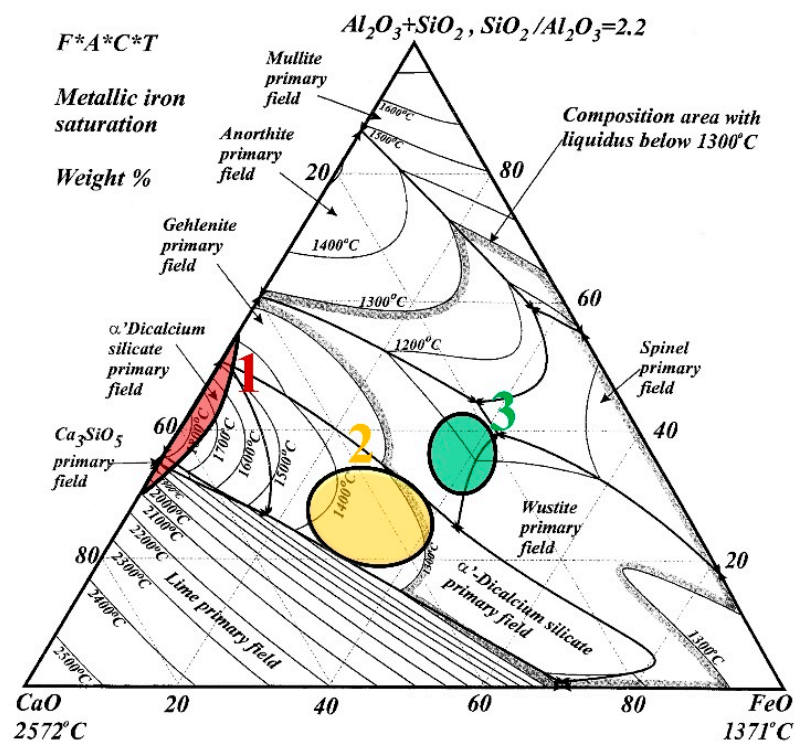

Figure 1. Samples identified on the $\mathrm{CaO}-\mathrm{FeO}-\mathrm{SiO}_{2}-\mathrm{Al}_{2} \mathrm{O}_{3}$ system with a $\mathrm{SiO}_{2} / \mathrm{Al}_{2} \mathrm{O}_{3}$ weight ratio of 2.2, reproduced from [31], with permission from Elsevier, 2001 


\subsection{Dephosphorization of Steels}

In this study, experiments were performed using $35 \mathrm{~kg}$ steel reinforcing bar and $200 \mathrm{~g}$ iron powder, and all the experiments were carried out under a normal atmosphere in an induction furnace (Five Power Electric Machinery Mfg. Corp., Taipei, Taiwan). The $35 \mathrm{~kg}$ steel reinforcing bar has a phosphorus content of $0.027 \mathrm{wt} . \%$. The furnace was heated at a rate of $20^{\circ} \mathrm{C} / \mathrm{min}$ up to $1520-1600{ }^{\circ} \mathrm{C}$. Ferrophosphorus was added to adjust the percentage of phosphorus in the molten metals to $0.04-0.05 \mathrm{wt} . \%$ (similar to the phosphorus content of scrap steel). The furnace output power ranging from $35 \mathrm{~kW}$ to $40 \mathrm{~kW}$ was controlled to maintain the necessary temperature, which are shown in Figure 2. A disposable type-B thermocouple was inserted into the molten metals every $5 \mathrm{~min}$ to measure the temperature and ensure that the molten metals were held at a fixed temperature (around $1550-1560^{\circ} \mathrm{C}$ ) for $10-20 \mathrm{~min}$. Supplements (Table 2) were then added for dephosphorization. The dephosphorization time was $20 \mathrm{~min}$. The molten metals were sampled at 0 and $20 \mathrm{~min}$. Finally, the chemical composition of the molten metals was examined by using an optical emission spectrometer (Q8 MAGELLAN, Bruker Corp., Hamburg, Germany). The final slag was analyzed by scanning electron microscopy with energy-dispersive X-ray spectroscopy (SEM-EDS) (IT-100, JEOL Ltd., Tokyo, Japan) and X-ray diffraction (XRD) (D8, Bruker Corp., Fremont, CA, USA).

Table 2. Materials of supplement, reagent grade $\mathrm{CaO}$, and $\mathrm{Al}_{2} \mathrm{O}_{3}$ were used. The amount of $\mathrm{Al}_{2} \mathrm{O}_{3}$ is $15 \%$ to $25 \%$ by weight of the slag, depending on the initial chemical composition of the LFS.

\begin{tabular}{lccc}
\hline \multicolumn{1}{c}{ Supplements } & LFS $(\mathbf{g})$ & $\mathbf{C a O}(\mathbf{g})$ & $\mathbf{A l}_{\mathbf{2}} \mathbf{O}_{\mathbf{3}} \mathbf{( \% )}$ \\
\hline $\mathrm{A}$ (for 200 g metal) & 3 & 3 & $15-25$ \\
$\mathrm{~A}$ & 525 & 525 & $15-25$ \\
$\mathrm{~B}$ & 1050 & 0 & $15-25$ \\
$\mathrm{C}$ & 0 & 1050 & $15-25$ \\
\hline
\end{tabular}

For the $200 \mathrm{~g}$ sample, the experiment differed from that for the $35 \mathrm{~kg}$ sample in certain aspects: Iron powder ( $>99 \%$ purity) was placed in an alumina crucible, which in turn was placed in a graphite crucible for heating. The furnace was heated until the desired equilibrium temperature was achieved, and supplements were then added into the molten metals for dephosphorization. The dephosphorization time was $6 \mathrm{~min}$. The molten metals were sampled at 0 and $6 \mathrm{~min}$. This test was performed only on the slag of LFS 1, LFS 2, and LFS 3 (Table 1). Each LFS was subjected to dephosphorization tests three times between 1520 and $1600{ }^{\circ} \mathrm{C}$ to ensure the repeatability of the experiment.

\subsection{XRD and SEM Analysis}

The slags were ground and polished for characterization at room temperature $\left(25^{\circ} \mathrm{C}\right)$ by XRD. Diffraction patterns were measured in a $2 \theta$ range of $20^{\circ}$ to $80^{\circ}$ by employing $\mathrm{Cu} \mathrm{K} \alpha$ radiation at $40 \mathrm{kV}$ and $30 \mathrm{~mA}$, and at a scan speed of $2^{\circ} \mathrm{min}^{-1}$. The local chemical composition of the slags was measured by SEM-EDS. SEM analysis in the backscattered electron imaging (BEI) mode was performed to identify and verify the different phases indicated by XRD patterns.

\subsection{Image-Pro-Plus Processing and Analysis}

Image-Pro Plus software (Media Cybernetics Inc., Rockville, MD, USA) was used to quantify the percentage of $\mathrm{C}_{2} \mathrm{~S}$ phase in the SEM-BEI images. Ten SEM-BEI images were randomly selected, and the $\mathrm{C}_{2} \mathrm{~S}$ phases were filled with color by Color Cube Base of Segmentation in the software. The area of the $\mathrm{C}_{2} \mathrm{~S}$ phase was calculated in units of pixels and then divided by the total area to calculate the percentage. 


\section{5. $f$-CaO Content Determination}

F-CaO content determination testing is carried out according to the patent 1600903 [32]. First, $100 \mathrm{~mL}$ of deionized water $\left(25^{\circ} \mathrm{C}\right)$ and $6 \mathrm{~g}$ of sucrose were added to an Erlenmeyer flask and then stirred until the sucrose completely dissolved. Then, $0.5 \mathrm{~g}$ of slag powder $(<2 \mathrm{~mm}$ particle size) was placed in the Erlenmeyer flask, covered with a cork stopper and stirred with magnetite for $2 \mathrm{~h}$. The solution in the Erlenmeyer flask was then filtered with No. 5C filter paper and was washed twice with 10-20 mL of deionized water. The filtrate was then collected in a flask, and $2.5 \mathrm{~mL}$ triethanolamine and $2.5 \mathrm{~mL}$ deionized water were added and poured into the filtrate. The $\mathrm{pH}$ of the filtrate was adjusted to 13 by using an aqueous solution of $30 \% \mathrm{KOH}$. When $0.3 \mathrm{~g}$ of the $\mathrm{NN}$ indicator was added to the filtrate, the filtrate turned magenta. Titration was carried out using $0.05 \mathrm{M}$ EDTA, and the terminal point was set when the filtrate turned from magenta to blue. The amount of $\mathrm{f}-\mathrm{CaO}$ can be calculated, as shown in Equation (5).

$$
\mathrm{f}-\mathrm{CaO}(\%)=\frac{\text { EDTA }(\mathrm{mL}) \times 28.04}{\text { sample weight }(\mathrm{g}) \times 100}
$$

\subsection{Laboratory-Scale Volume Expansion Testing}

Volume-expansion testing is carried out according to the potential expansion test method (ASTM D4792). The experimental method was described in detail by Wang et al. [33] and Deniz et al. [28]. In this work, the particle size of the oxidizing slag and LFS is $2.36-5 \mathrm{~mm}$ and $0.84-2 \mathrm{~mm}$, respectively. The weight of the sample was $7-8 \mathrm{~kg}$. The sample was measured using a dial gauge and compacted in standard molds (diameter $=1520 \mathrm{~mm}$, height $=1650 \mathrm{~mm}$ ). The sample was then immersed in hot water at a temperature of $70 \pm 3{ }^{\circ} \mathrm{C}$ for seven days. During the test, an additional load of $4.54 \mathrm{~kg}$ was applied to the sample for seven days. In accordance with ASTM D2940, if the expansion of the sample is below $0.05 \%$ within seven days, then the sample can be used for preparing paving materials.

\section{Results and Discussion}

\subsection{Dephosphorization of Modified Oxidizing Slag}

In conventional EAF steelmaking operations, the phosphorus content of scrap steel is about $0.03-0.05 \%$. The phosphorus content of general engineering steel is less than $0.03 \%$ to meet set standards. Therefore, when the dephosphorization rate reaches $40 \%$, the phosphorus content of the steel can be lower than $0.03 \%$. Lime is usually added for dephosphorization, and the temperature is continuously raised to above $1580{ }^{\circ} \mathrm{C}$, before the final stage of LF refining. It is known that dephosphorization involves an exothermic reaction, and the dephosphorization ability decreases as the temperature increases. Therefore, the relationship between the dephosphorization rate and temperature is important for phosphorus-content calculations in a steel plant. The focus of this study is whether a wide range of LFS can use this approach to reduce phosphorus content to less than $0.03 \%$ (dephosphorization rate above $40 \%$ ) and enable most LFS applications to meet the set standards of general engineering steel. In addition, LFSs 1-6 are already in the three types (Table 1). We believe that LFSs 1-6 are already representative, so LFSs 7-10 were not tested for dephosphorization.

Figure 2 shows the dephosphorization rate of modified oxidizing slag at different temperatures, and the materials of the supplement are shown in Table 2. Table 3 lists the results for different slag compositions. The experimental results showed that the dephosphorization rate when supplement $\mathrm{A}$ was used was $>45 \%$, and that when supplement $B$ was used was lower. Furthermore, two dephosphorization tests of samples S5A and S5B showed that S5A could greatly improve the dephosphorization rate. In the control group without LFS (S-C), the dephosphorization rate was more than $80 \%$. Supplement A can consume a part of LFS, resulting in the phosphorus content of the molten metal becoming $<0.03 \mathrm{wt} . \%$. 


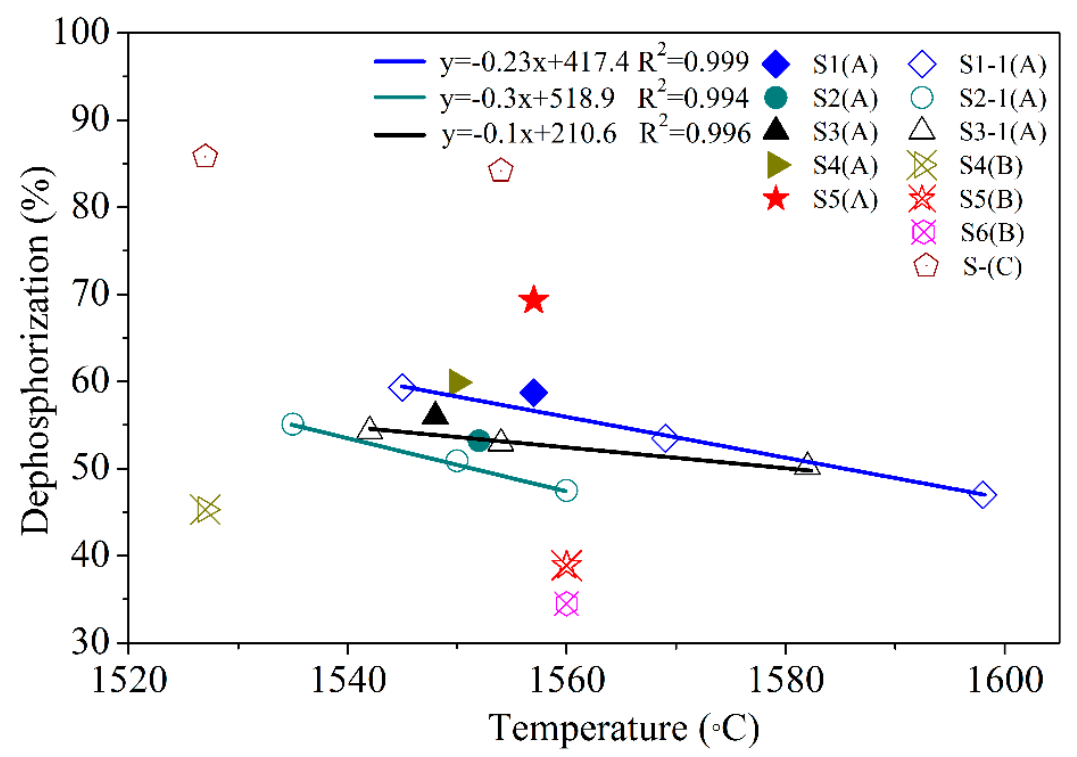

Figure 2. Relationship between the dephosphorization rate and temperature. $\mathrm{S} 1(\mathrm{~A})$ is $\mathrm{LF} 1+\mathrm{CaO}+$ $\mathrm{Al}_{2} \mathrm{O}_{3}, \mathrm{~S} 4$ (B) is $\mathrm{LF} 4+\mathrm{Al}_{2} \mathrm{O}_{3}$. S1-1 (A), S2-1 (A), and S3-1 (A) are tests for $200 \mathrm{~g}$ of metal.

Figure 2 shows that the dephosphorization rate and temperature can be fitted to a linear function. The slope values for samples S1-1(A), S2-1(A), and S3-1(A) were $-0.23,-0.3$, and -0.1 , respectively. The composition of three types of LFS varied considerably (Table 1), affecting the slope of dephosphorization. The slope indicates the temperature sensitivity of the slags during the dephosphorization process. If the slag temperature sensitivity is low, it is possible to reduce the phosphorus from the molten slag and transfer it to the molten steel (rephosphorization). Sample S3-1(A) had the lowest temperature sensitivity and the largest slope of dephosphorization. Therefore, it was more stable than S1-1(A) and S2-1(A): its dephosphorization results do not vary greatly due to temperature changes. The reason for this could be that as the MgO content in the LFS 3 slag was $17.9 \%$ (Table 1), the slag melting point was higher than those of LFS 1 and LFS 2, and the rate of rephosphorization was reduced. In addition, the slope of S2-(A) was the smallest, and the dephosphorization rate decreased significantly as the temperature increased. The reason for this could be that because $\mathrm{Al}_{2} \mathrm{O}_{3}$ in the LFS 2 slag was $19.9 \%$ (Table 1), dephosphorization was limited in the initial stages of melting as most of the $\mathrm{C}_{2} \mathrm{~S}$ phase had been replaced by $\mathrm{Al}_{2} \mathrm{O}_{3}$. According to this analysis, the dephosphorization rates of the high-SiO ${ }_{2}$-content slag (LFS 1) and the high-MgO-content slag (LFS 3) were still more than $50 \%$ at 1580 ${ }^{\circ} \mathrm{C}$ in case of a modification of the slags with $\mathrm{Al}_{2} \mathrm{O}_{3}$.

Table 3. The compositions of the slag; square brackets indicate the concentration in the metal.

\begin{tabular}{|c|c|c|c|c|c|c|c|c|}
\hline \multirow{2}{*}{ Sample } & \multicolumn{5}{|c|}{ Chemical Composition (wt.\%) } & \multirow{2}{*}{$\begin{array}{c}\text { Initial } \\
{[\mathbf{P}]}\end{array}$} & \multirow{2}{*}{$\begin{array}{c}\text { Final } \\
{[P]}\end{array}$} & \multirow{2}{*}{$\begin{array}{c}\text { De-P } 1 \\
(\%)\end{array}$} \\
\hline & $\mathrm{CaO}$ & $\mathrm{SiO}_{2}$ & $\mathrm{Al}_{2} \mathrm{O}_{3}$ & $\mathrm{Fe}_{\mathrm{x}} \mathrm{O}$ & $\mathrm{P}_{2} \mathrm{O}_{5}$ & & & \\
\hline S1 (A) & 24.4 & 8.4 & 21.7 & 41.3 & 0.551 & 0.0477 & 0.0197 & 58.7 \\
\hline S2 (A) & 25.8 & 7.9 & 20.1 & 40.2 & 0.455 & 0.0451 & 0.0211 & 53.2 \\
\hline S3 (A) & 24.5 & 8.6 & 17.6 & 44.5 & 0.546 & 0.0432 & 0.0191 & 55.8 \\
\hline S4 (A) & 27.2 & 7.3 & 22.3 & 27.2 & 0.643 & 0.0389 & 0.0156 & 59.9 \\
\hline S5 (A) & 22.3 & 8.1 & 20.4 & 33.6 & 0.757 & 0.0496 & 0.0152 & 69.4 \\
\hline S4 (B) & 23.4 & 9.9 & 15.3 & 35.6 & 0.445 & 0.0403 & 0.0221 & 45.2 \\
\hline S5 (B) & 16.6 & 13.9 & 20.3 & 33.8 & 0.375 & 0.0314 & 0.0192 & 38.9 \\
\hline S6 (B) & 20.8 & 8.8 & 24.8 & 25.9 & 0.397 & 0.0495 & 0.0324 & 34.5 \\
\hline S-(C) & 32.1 & 4.3 & 28.7 & 26.2 & 0.844 & 0.0514 & 0.0081 & 84.2 \\
\hline
\end{tabular}




\section{2. $X R D$ Analysis}

Figure 3 presents the XRD analysis results. Different LFSs (Figure 3a) have $\mathrm{C}_{2} \mathrm{~S}, \mathrm{C}_{3} \mathrm{~S}, \mathrm{CaO}$, and $\mathrm{MgO}$ as the major phases. These phases were common in the LFS [34,35] and are the reason for the high probability of slag expansion. Slags with the $\mathrm{C}_{2} \mathrm{~S}$ phase were classified as potentially hazardous waste. EAFSs (Figure $3 b$ ) have $\mathrm{C}_{2} \mathrm{~S}$ and $\mathrm{FeO}$ as the major phases. In addition, the $\mathrm{C}_{2} \mathrm{~S}$ peak has the highest intensity. The modified oxidizing slags after dephosphorization exhibited obvious structural phase transformations, and the major phases were $\mathrm{FeO}$ and $\mathrm{Ca}_{2} \mathrm{Al}_{2} \mathrm{SiO}_{7}$ (Figure $3 \mathrm{~b}$ ). The $\mathrm{FeO}$ phase is a stable, inert phase [16]. Some studies $[25,26]$ have shown that larnite $\left(\beta\right.$ or $\left.\gamma-C_{2} S\right)$ is the main phase that undergoes hydration during the leaching of slags, which is the primary cause of the release of $\mathrm{V}$ and $\mathrm{Ba}$, and is the main factor controlling the properties of the leaching solution. $\mathrm{Ca}_{2} \mathrm{Al}_{2} \mathrm{SiO}_{7}$ is a stable phase that seems to improve the slag resistance against dissolution. In addition, because $\mathrm{Ca}_{2} \mathrm{Al}_{2} \mathrm{SiO}_{7}$ is a non-hydraulic phase, while $\mathrm{C}_{2} \mathrm{~S}$ is hydrated phase, the former does not expand unlike slag containing $\mathrm{C}_{2} \mathrm{~S}$. Therefore, this method can not only replace part of the lime in dephosphorization but also transform unstable LFSs into stable oxidizing slag. Thus, many of the problems associated with slag recycling are solved.

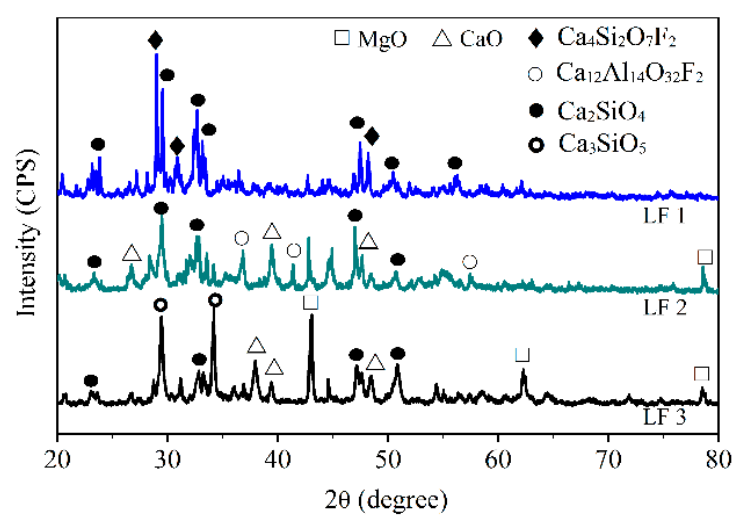

(a)

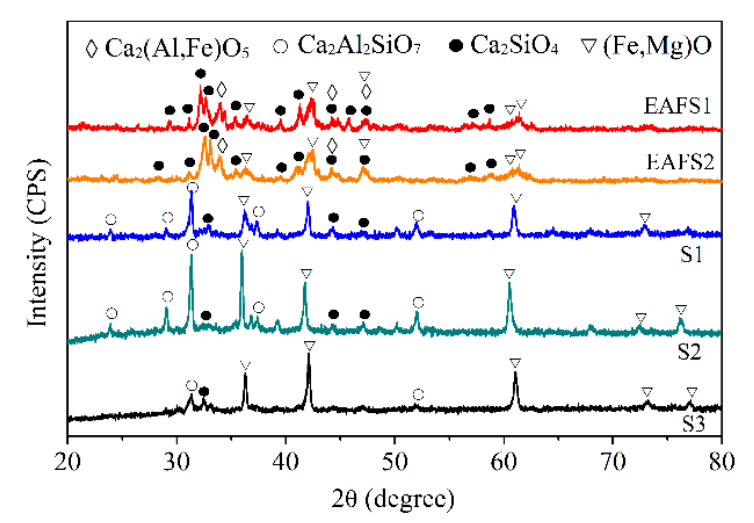

(b)

Figure 3. XRD results of (a) LFS; (b) EAFS and modified oxidizing slags.

\subsection{SEM Analysis}

The microstructure development in the phosphorus-enriched phase was analyzed by SEM-EDS. The effect of alumina on the dephosphorization process and the change in the $\mathrm{C}_{2} \mathrm{~S}$ phase were observed. Figure 4 shows the SEM-BEI image of the oxidizing slags listed in Table 4, during furnace cooling.

In four samples, phase I, i.e., $\mathrm{FeO}$ and phase III, i.e., $\mathrm{C}_{2} \mathrm{~S}$ were dispersed in phase II, i.e., the matrix. Wustite (white) was the main $\mathrm{FeO}$ or $(\mathrm{Mg}, \mathrm{Fe}) \mathrm{O}$ phase and had a dendritic form. The black striped phase III was dicalcium silicate with some aluminate. In the four samples, phosphorus was only present in phase III (Table 4). As shown in Equation (4), the phosphorus was in the form of a $\mathrm{Ca}_{3} \mathrm{P}_{2} \mathrm{O}_{8} \cdot \mathrm{Ca}_{2} \mathrm{SiO}_{4}$ solid solution in the slag. With the increase in the amount of $\mathrm{Al}_{2} \mathrm{O}_{3}, \mathrm{C}_{2} \mathrm{~S}$ gradually disappeared. The chemical composition of phase III in $\mathrm{S} 1$ and $\mathrm{S} 3$ showed that the $\mathrm{Al}$ content increases to about 2-8\%. This indicates that some $\mathrm{Al}$ atoms replaced the $\mathrm{Si}$ atoms and dissolved into the $\mathrm{C}_{2} \mathrm{~S}$ phase to form $\mathrm{Ca}_{2}$ $(\mathrm{Al}, \mathrm{Si}) \mathrm{O}_{4}$. 


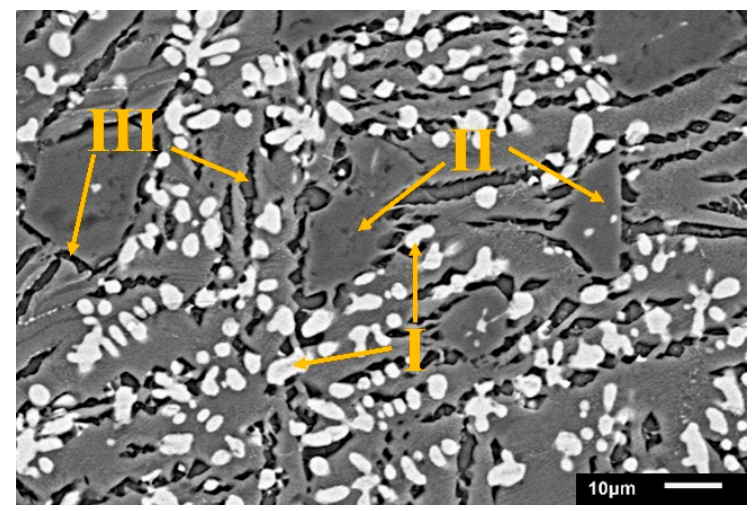

(a)

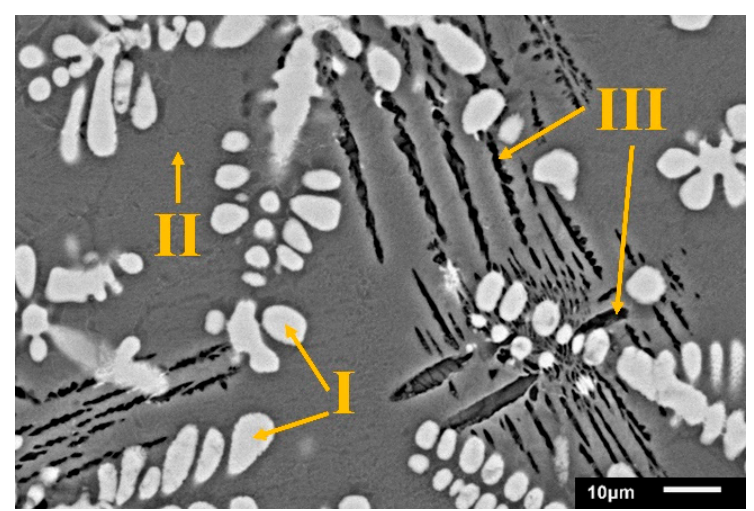

(c)

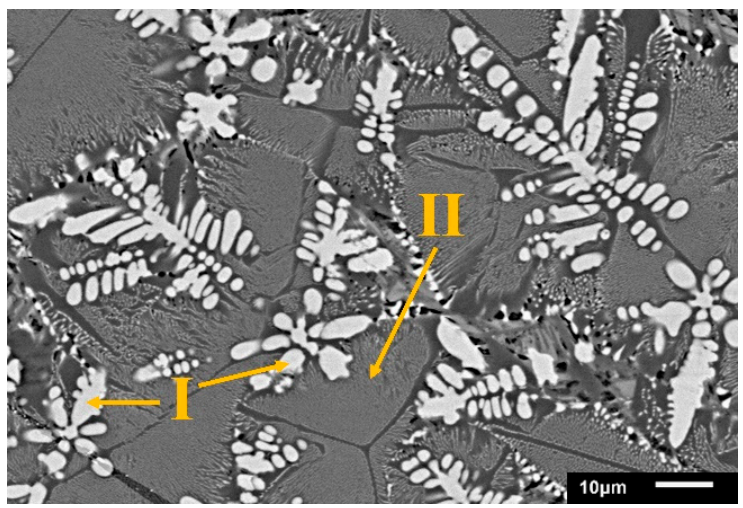

(b)

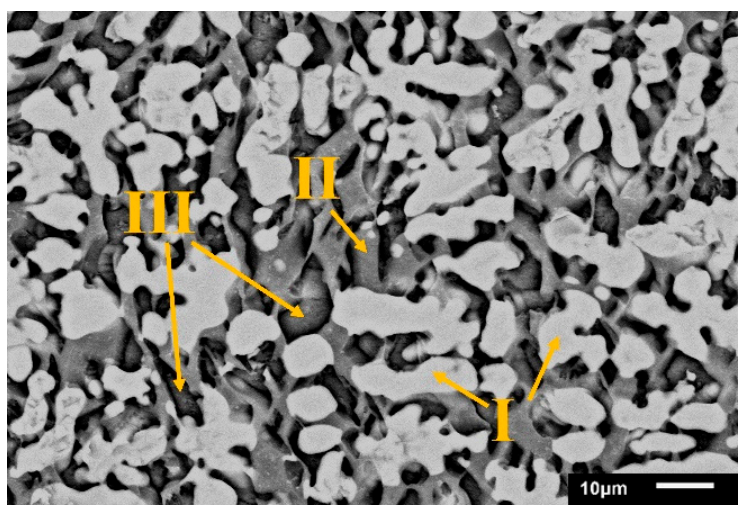

(d)

Figure 4. SEM-BEI of modified oxidizing slags after dephosphorization (a) S1; (b) S2; (c) S3; and the control group from a steel plant $(\mathbf{d})$ EAFS (Phase I = FeO; Phase II = matrix; Phase $\mathrm{III}=\mathrm{C}_{2} \mathrm{~S}$ ).

Table 4. Chemical composition of each phase shown by SEM-EDS.

\begin{tabular}{clccccccc}
\hline \multirow{2}{*}{ Sample } & \multirow{2}{*}{ Phase } & \multicolumn{7}{c}{ Chemical Composition, at.\% } \\
\cline { 2 - 9 } & & $\mathbf{C a}$ & $\mathbf{S i}$ & $\mathbf{A l}$ & $\mathbf{F e}$ & $\mathbf{M g}$ & $\mathbf{P}$ & $\mathbf{O}$ \\
\hline \multirow{3}{*}{ S1 } & I-FeO & 1.9 & 0.0 & 0.6 & 41.1 & 6.6 & 0.00 & 49.8 \\
\cline { 2 - 9 } & II-matrix & 14.8 & 5.8 & 14.0 & 7.1 & 0.8 & 0.00 & 57.4 \\
\cline { 2 - 9 } & III-C $2 \mathrm{~S}$ & 25.7 & 10.4 & 2.6 & 1.1 & 0.3 & 0.32 & 59.5 \\
\hline \multirow{2}{*}{ S2 } & I-FeO & 2.5 & 0.2 & 0.9 & 40.1 & 7.6 & 0.00 & 48.7 \\
\cline { 2 - 9 } & II-matrix & 14.5 & 5.3 & 14.5 & 8.7 & 1.2 & 0.00 & 55.9 \\
\hline \multirow{2}{*}{ S3 } & I-FeO & 0.9 & 0.0 & 0.4 & 36.7 & 13.1 & 0.00 & 48.9 \\
\cline { 2 - 9 } & II-matrix & 15.1 & 6.1 & 13.2 & 5.8 & 1.0 & 0.00 & 58.9 \\
\cline { 2 - 9 } & III-C $2 S$ & 28.6 & 8.2 & 7.3 & 1.1 & 0.4 & 0.28 & 54.1 \\
\hline \multirow{2}{*}{ EAFS } & I-FeO & 1.1 & 0.2 & 0.7 & 35.8 & 8.3 & 0.00 & 53.9 \\
\cline { 2 - 9 } & II-matrix & 13.3 & 4.6 & 14.8 & 4.5 & 0.1 & 0.00 & 61.9 \\
\cline { 2 - 9 } & III-C $2 S$ & 33.1 & 17.5 & 0.4 & 1.0 & 0.1 & 0.47 & 47.4 \\
\hline
\end{tabular}

\subsection{Image-Pro-Plus Analysis}

To understand the effect of $\mathrm{Al}_{2} \mathrm{O}_{3}$ on the $\mathrm{C}_{2} \mathrm{~S}$ phase (phase III in Figure 4), Image-Pro Plus software was used for analysis. Figure 5 shows the images of the $C_{2} S$ phase (filled the black striped with red 
by the software). As can be seen from the figure, the software can almost identify the $\mathrm{C}_{2} \mathrm{~S}$ phase (i.e., the black striped phase III). The red area of EAFS is larger than the red area of S4 (B). Figure 6 shows the effect of $\mathrm{Al}_{2} \mathrm{O}_{3}$ on the $\mathrm{C}_{2} \mathrm{~S}$ phase. The results show that as the $\mathrm{Al}_{2} \mathrm{O}_{3}$ content exceeds $15 \%$, the percentage of the $\mathrm{C}_{2} \mathrm{~S}$ phase decreases from an average of 31.4 to $17.1 \%$, and the $\mathrm{C}_{2} \mathrm{~S}$ phase exists as a solid solution with 2-8\% Al atoms (Table 4). The EAFS and modified oxidizing slag are showing in Figure 7. It was also confirmed from Figure 7 that the major phase of the slag is $\mathrm{C}_{2} \mathrm{Al}_{2} \mathrm{SiO}_{7}$.

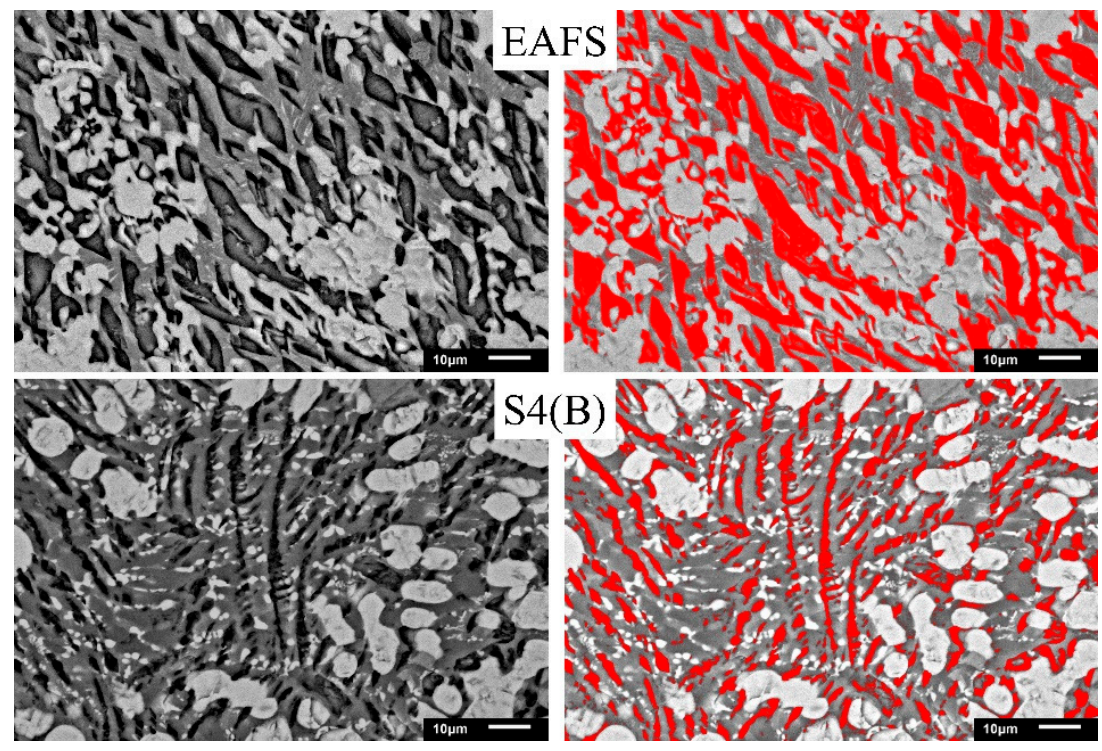

Figure 5. $\mathrm{C}_{2} \mathrm{~S}$ phase analysis of EAFS and $\mathrm{S} 4(\mathrm{~B})$.

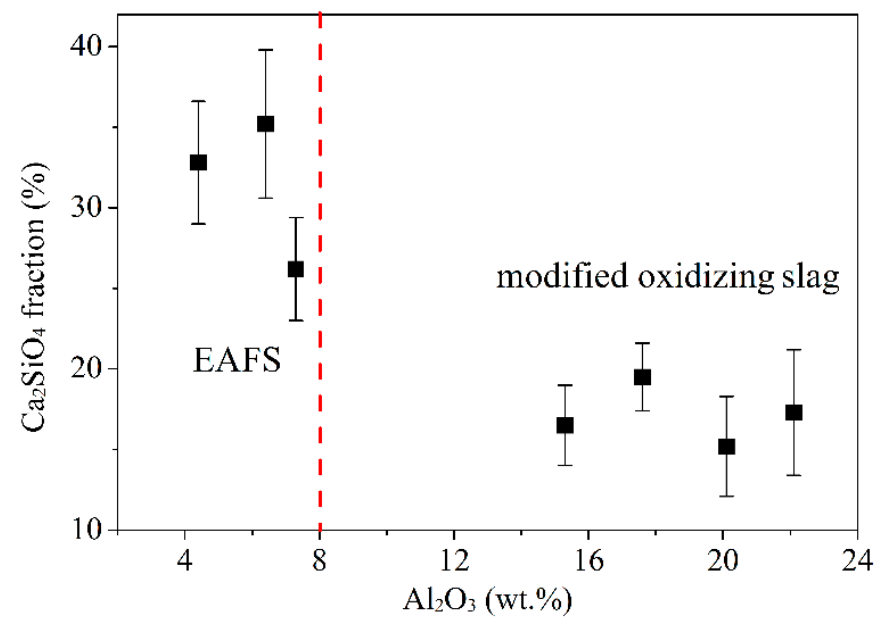

Figure 6. Effect of $\mathrm{Al}_{2} \mathrm{O}_{3}$ content on $\mathrm{C}_{2} \mathrm{~S}$ fraction of EAFS and modified oxidizing slag.

It can be concluded that three phase transformations took place successively during the dephosphorization of the molten slag. The complete phase transformation mechanisms of the slag are shown schematically in Figure 8. First, LFS was added to the molten metal. The main crystalline phases of LFS are $\mathrm{CaO}, \mathrm{MgO}$, $\mathrm{C}_{2} \mathrm{~S}$, and $\mathrm{C}_{3} \mathrm{~S}$. The slag then produced about $20-40 \% \mathrm{FeO}$ after the metal oxidation, which changed the phase of the LFS. In addition, the main phase of the slag was either $\mathrm{C}_{2} \mathrm{~S}$ or FeO, which is common in the case of EAFS, and $\mathrm{P}_{2} \mathrm{O}_{5}$ was also present in the $\mathrm{C}_{2} \mathrm{~S}$ phase [27]. Finally, as $\mathrm{Al}_{2} \mathrm{O}_{3}$ started to melt, $\mathrm{Al}_{2} \mathrm{O}_{3}$ in the slag began to reduce the amount of the $\mathrm{C}_{2} \mathrm{~S}$ phase. The final modified oxidizing slag was mainly composed of $\mathrm{FeO}, \mathrm{Ca}_{2} \mathrm{Al}_{2} \mathrm{SiO}_{7}$, and a small amount of $\mathrm{C}_{2} \mathrm{~S}$ or $\mathrm{Ca}_{2}(\mathrm{Al}, \mathrm{Si}) \mathrm{O}_{4}$. 


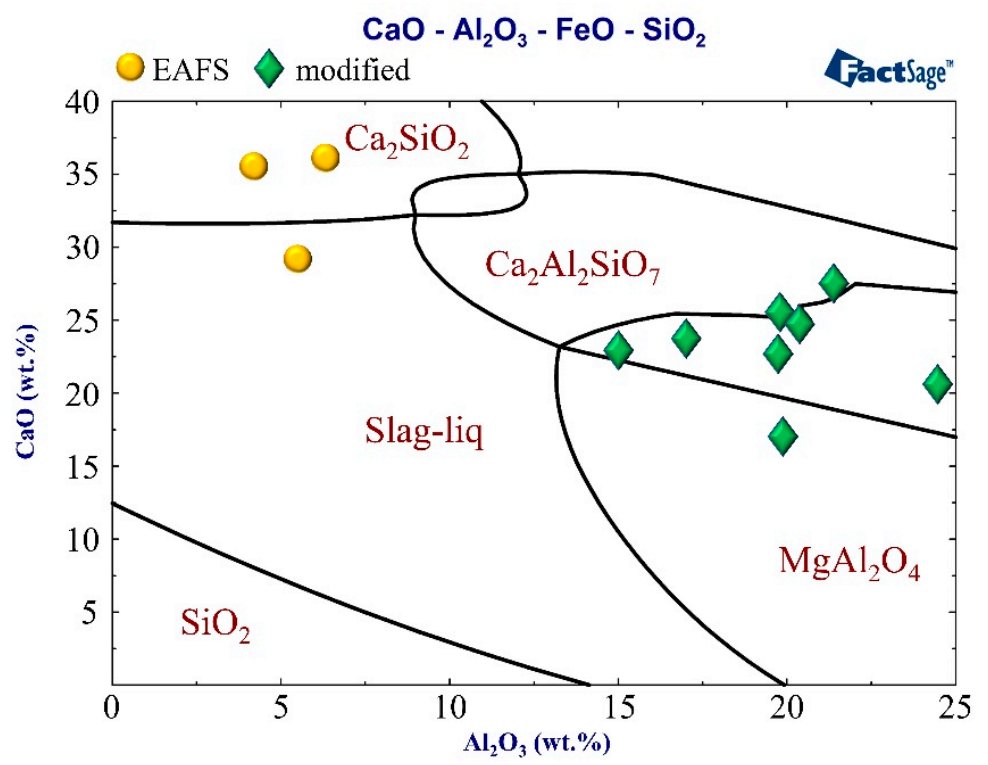

Figure 7. Samples identified on the $\mathrm{CaO}-40 \mathrm{FeO}-\mathrm{SiO}_{2}-\mathrm{Al}_{2} \mathrm{O}_{3}$ system at $1250{ }^{\circ} \mathrm{C}$.

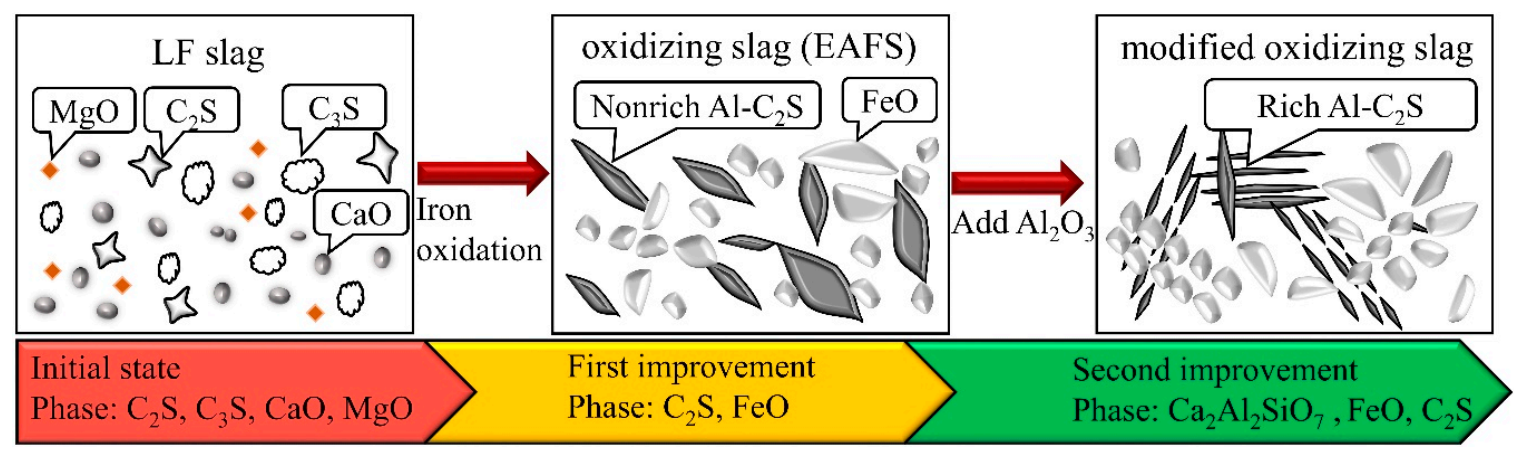

Figure 8. Schematic diagram showing the phase transition from LFS to modified oxidizing slag in the dephosphorization process and the crystalline phases of each stage.

\subsection{Comparison of Expansion and $\mathrm{f}-\mathrm{CaO}$ Results}

Further study of slag expansion and the $\mathrm{f}-\mathrm{CaO}$ content are necessary to estimate the stability of the modified oxidizing slag. The slag-volume-expansion tests were performed according to ASTM D4792. According to ASTM D2940, the steel slag aggregates contain easily hydrated components, and the expansion values should not be more than $0.50 \%$ within seven days [28]. Therefore, the slag with no more than $0.5 \%$ expansion could be used for preparing paving materials.

It is well known that $\mathrm{f}-\mathrm{CaO}$ can undergo hydration and expansion. As the $\mathrm{f}-\mathrm{CaO}$ content of the slag increases, the slag volume also increases as a result of expansion. Therefore, the $\mathrm{f}-\mathrm{CaO}$ content of the slag should be reduced as much as possible to control the volume expansion of the slag. The $\mathrm{f}-\mathrm{CaO}$ content and volume expansion for various types of LFS are shown in Figure 9a. It shows that a 2.5-3.5\% $\mathrm{f}-\mathrm{CaO}$ content results in an expansion that varies greatly from $1 \%$ to $5 \%$. This result also verifies the instability of LFS. Figure $9 \mathrm{~b}$ shows the $\mathrm{f}-\mathrm{CaO}$ and volume expansion of the modified oxidizing slag and EAFS. The detailed data is presented in Table 5. In this study, the expansion of the oxidizing slag was less than $0.5 \%$. Furthermore, for unmodified EAFS, the $\mathrm{f}-\mathrm{CaO}$ content is as high as $1.4 \%$. However, the $\mathrm{f}-\mathrm{CaO}$ content of the modified oxidizing slag is only $0.13-0.41 \%$. The results show that as the $\mathrm{CaO}$ content in the supplement increases, the $\mathrm{f}-\mathrm{CaO}$ content tends to increase. This means that the addition of $\mathrm{LF}$ and $\mathrm{Al}_{2} \mathrm{O}_{3}$ can reduce the concentration of $\mathrm{f}-\mathrm{CaO}$ in $\mathrm{CaO}$.

Thus, the experimental results showed that the LFS with more than $2.5 \% \mathrm{f}-\mathrm{CaO}$ content could be transformed into oxidizing slag with $0.41 \% \mathrm{f}-\mathrm{CaO}$ content by modification at $1520-1600^{\circ} \mathrm{C}$. Although 
the volume expansions of modified oxidizing slag and EAFS are significantly different, the values $(0.037 \%$ and $0.17 \%$, respectively) are lower than $0.5 \%$, as required by the ASTM D2940 standards. Therefore, the modified oxidizing slag can be used for preparing paving materials.

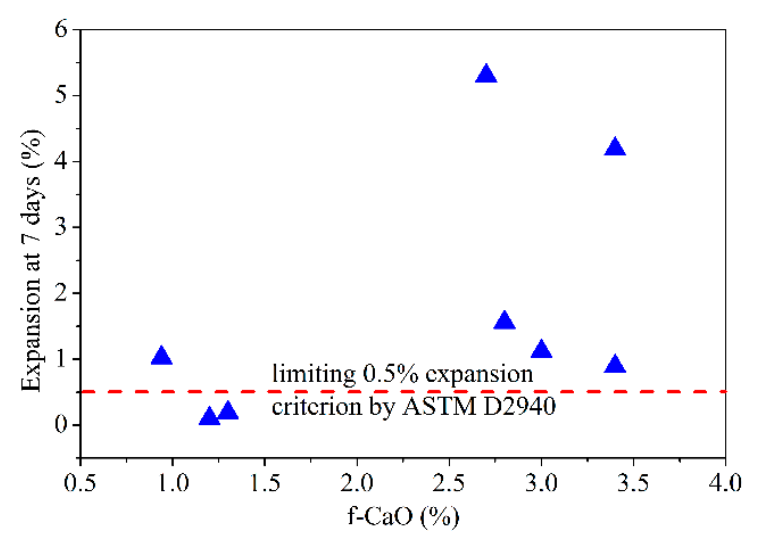

(a)

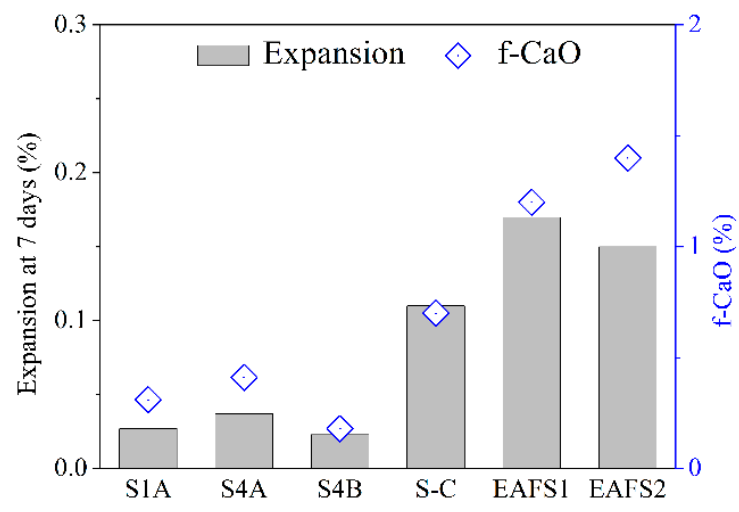

(b)

Figure 9. The content of $\mathrm{f}-\mathrm{CaO}$ and volume expansion for various types of slag: (a) LFS; (b) modified oxidizing slag and EAFS.

Table 5. The results of $\mathrm{f}-\mathrm{CaO}$ and volume expansion for oxidizing slag.

\begin{tabular}{lccccccccccc}
\hline \multicolumn{1}{c}{ Sample } & S1A & S2A & S3A & S4A & S5A & S4B & S5B & S6B & S-C & EAF1 & EAF2 \\
\hline f-CaO (\%) & 0.31 & 0.31 & 0.26 & 0.41 & 0.37 & 0.18 & 0.13 & 0.21 & 0.7 & 1.2 & 1.4 \\
Expansion (\%) & 0.027 & NA $^{1}$ & NA $^{1}$ & 0.037 & NA $^{1}$ & 0.023 & 0.029 & NA $^{1}$ & 0.11 & 0.17 & 0.15 \\
\hline
\end{tabular}

${ }^{1} \mathrm{NA}=$ Not Analyzed.

\section{Conclusions}

In this study, surplus $\mathrm{CaO}$ in LFS was used as a substitute for the lime material required in dephosphorization. Through the addition of $\mathrm{Al}_{2} \mathrm{O}_{3}$, the LFS was transformed into oxidizing slag with lower $\mathrm{f}-\mathrm{CaO}$. The major findings are summarized as follows:

(1) The dephosphorization rate of different LFSs using supplement $\mathrm{A}\left(\mathrm{LF} / \mathrm{CaO}=1 / 1, \mathrm{Al}_{2} \mathrm{O}_{3}\right.$ content $=15-25 \%$ ) was more than $45 \%$ between $1520{ }^{\circ} \mathrm{C}$ and $1600{ }^{\circ} \mathrm{C}$. The phosphorus content of steel is less than $0.03 \%$ to meet the set standards of general engineering steel.

(2) XRD results showed that different LFSs had $\mathrm{C}_{2} \mathrm{~S}, \mathrm{C}_{3} \mathrm{~S}, \mathrm{CaO}$, and $\mathrm{MgO}$ as the major phases. The characteristics of LFS were altered after high-temperature slag modification, and the primary crystalline phases were $\mathrm{FeO}$ and gehlenite $\left(\mathrm{Ca}_{2} \mathrm{Al}_{2} \mathrm{SiO}_{7}\right)$.

(3) SEM analysis confirmed that phosphorus was concentrated in the $\mathrm{C}_{2} \mathrm{~S}$ phase during dephosphorization. As the $\mathrm{Al}_{2} \mathrm{O}_{3}$ content exceeds $15 \%$, about $2-8 \%$ of $\mathrm{Al}$ atoms replaced $\mathrm{Si}$ atoms, and the $\mathrm{C}_{2} \mathrm{~S}$ phase fraction decreased from $31.4 \%$ to $17.1 \%$.

(4) The f-CaO content of the modified oxidizing slag was less than $0.41 \%$ (while those of LFS and EAFS were $0.9-3.4 \%$ and $1.2-1.4 \%$, respectively). The modified oxidizing slag showed almost no expansion and conformed to the ASTM D2940 standards.

Author Contributions: Conceptualization, C.-C.L. and C.-M.L.; formal analysis, C.-C.L.; funding acquisition, W.W.; investigation, Y.-E.C. and W.-T.C.; methodology, C.-C.L. and Y.-E.C.; project administration, W.W.; supervision, W.W.; validation, C.-M.L., Y.-E.C. and W.-T.C.; writing-original draft, C.-C.L.; writing-review \& editing, C.-M.L. and Y.-E.C. All authors have read and agreed to the published version of the manuscript.

Funding: This work was supported by the Ministry of Science and Technology, Taiwan, under projects numbered MOST 108-2218-E-005-005 and MOST 108-2218-E-005-019. 
Acknowledgments: The authors would like to thank the members of the materials science and engineering at National Chung Hsing University.

Conflicts of Interest: The authors declare no conflict of interest.

\section{References}

1. Setien, J.; Hernandez, D.; Gonzalez, J.J. Characterization of ladle furnace basic slag for use as a construction material. Constr. Build. Mater. 2009, 23, 1788-1794. [CrossRef]

2. Durinck, D.; Arnout, S.; Mertens, G.; Boydens, E.; Jones, P.T.; Elsen, J.; Blanpain, B.; Wollants, P. Borate distribution in stabilized stainless-steel slag. J. Am. Ceram. Soc. 2008, 91, 548-554. [CrossRef]

3. Shi, C.J. Characteristics and cementitious properties of ladle slag fines from steel production. Cem. Concr. Res. 2002, 32, 459-462. [CrossRef]

4. Shi, C.J.; Qian, J.S. High performance cementing materials from industrial slags-A review. Resour. Conserv. Recycl. 2000, 29, 195-207. [CrossRef]

5. Lee, H.-S.; Lim, H.-S.; Ismail, M.A. Quantitative evaluation of free cao in electric furnace slag using the ethylene glycol method. Constr. Build. Mater. 2017, 131, 676-681. [CrossRef]

6. Loncnar, M.; van der Sloot, H.A.; Mladenovic, A.; Zupancic, M.; Kobal, L.; Bukovec, P. Study of the leaching behaviour of ladle slags by means of leaching tests combined with geochemical modelling and mineralogical investigations. J. Hazard. Mater. 2016, 317, 147-157. [CrossRef]

7. Bocci, E. Use of ladle furnace slag as filler in hot asphalt mixtures. Constr. Build. Mater. 2018, 161, $156-164$. [CrossRef]

8. Worldsteel. Steel Statistical Yearbook. Available online: https://www.worldsteel.org/steel-by-topic/statistics/ steel-statistical-yearbook.html (accessed on 27 March 2020).

9. Serjun, V.Z.; Mirtic, B.; Mladenovic, A. Evaluation of ladle slag as a potential material for building and civil engineering. Mater. Tehnol. 2013, 47, 543-550.

10. Branca, T.A.; Colla, V.; Valentini, R. A way to reduce environmental impact of ladle furnace slag. Ironmak. Steelmak. 2009, 36, 597-602. [CrossRef]

11. Okoye, P.U.; Abdullah, A.Z.; Hameed, B.H. Stabilized ladle furnace steel slag for glycerol carbonate synthesis via glycerol transesterification reaction with dimethyl carbonate. Energy Conv. Manag. 2017, 133, 477-485. [CrossRef]

12. Gu, X.; Yu, B.; Dong, Q.; Deng, Y. Application of secondary steel slag in subgrade: Performance evaluation and enhancement. J. Clean. Prod. 2018, 181, 102-108. [CrossRef]

13. Papayianni, I.; Anastasiou, E. Effect of granulometry on cementitious properties of ladle furnace slag. Cem. Concr. Compos. 2012, 34, 400-407. [CrossRef]

14. Guzzon, M.; Mapelli, C.; Sahajwalla, V.; Saha-Chaudhury, N.; Memoli, F.; Pustorino, M. The behaviour of the secondary metallurgy slag into the eaf. How to create a good foamy slag with the appropriate basicity using a mix of lime and recycled ladle slag as eaf slag former. In Proceedings of the 38th Seminário de Aciaria, Belo Horizonte, Brazil, 14 November 2019.

15. Li, J.X.; Yu, Q.J.; Wei, J.X.; Zhang, T.S. Structural characteristics and hydration kinetics of modified steel slag. Cem. Concr. Res. 2011, 41, 324-329. [CrossRef]

16. Wang, Q.A.; Yan, P.Y.; Feng, J.W. A discussion on improving hydration activity of steel slag by altering its mineral compositions. J. Hazard. Mater. 2011, 186, 1070-1075. [CrossRef] [PubMed]

17. Wang, Q.; Wang, D.Q.; Zhuang, S.Y. The soundness of steel slag with different free cao and mgo contents. Constr. Build. Mater. 2017, 151, 138-146. [CrossRef]

18. Rashad, A.M. A synopsis manual about recycling steel slag as a cementitious material. J. Mater. Res. Technol. 2019, 8, 4940-4955. [CrossRef]

19. Guzzon, M.; Mapelli, C.; Memoli, F.; Marcozzi, M. Recycling of ladle slag in the eaf: Improvement of the foaming behaviour and decrease of the environmental impact. Rev. de Métall. 2007, 104, 171-178. [CrossRef]

20. Varanasi, S.S.; More, V.M.R.; Rao, M.B.V.; Alli, S.R.; Tangudu, A.K.; Santanu, D. Recycling ladle furnace slag as flux in steelmaking: A review. J. Sustain. Metall. 2019, 5, 449-462. [CrossRef]

21. Skaf, M.; Manso, J.M.; Aragón, Á.; Fuente-Alonso, J.A.; Ortega-López, V. Eaf slag in asphalt mixes: A brief review of its possible re-use. Resour. Conserv. Recycl. 2017, 120, 176-185. [CrossRef] 
22. Yildirim, I.Z.; Prezzi, M. Experimental evaluation of eaf ladle steel slag as a geo-fill material: Mineralogical, physical \& mechanical properties. Constr. Build. Mater. 2017, 154, 23-33. [CrossRef]

23. Brand, A.S.; Roesler, J.R. Steel furnace slag aggregate expansion and hardened concrete properties. Cem. Concr. Compos. 2015, 60, 1-9. [CrossRef]

24. González-Ortega, M.A.; Cavalaro, S.H.P.; de Rodríguez Sensale, G.; Aguado, A. Durability of concrete with electric arc furnace slag aggregate. Constr. Build. Mater. 2019, 217, 543-556. [CrossRef]

25. Mombelli, D.; Mapelli, C.; Barella, S.; Gruttadauria, A.; Le Saout, G.; Garcia-Diaz, E. The efficiency of quartz addition on electric arc furnace (eaf) carbon steel slag stability. J. Hazard. Mater. 2014, 279, 586-596. [CrossRef] [PubMed]

26. Mombelli, D.; Mapelli, C.; Barella, S.; Di Cecca, C.; Le Saout, G.; Garcia-Diaz, E. The effect of microstructure on the leaching behaviour of electric arc furnace (eaf) carbon steel slag. Proc. Saf. Environ. Protect. 2016, 102, 810-821. [CrossRef]

27. Suito, H.; Inoue, R. Behavior of phosphorous transfer from cao-feto-p2o5(-sio2) slag to cao particles. ISIJ Int. 2006, 46, 180-187. [CrossRef]

28. Deniz, D.; Tutumluer, E.; Popovics, J.S. Evaluation of expansive characteristics of reclaimed asphalt pavement and virgin aggregate used as base materials. Transp. Res. Rec. 2010, 10-17. [CrossRef]

29. Li, C.C.; Lin, C.M.; Hung, C.Y.; Chang, K.L.; Wu, W.T. Effect of al2o3/sio2 ratio on viscosity and structure of cao-al2o3-sio2-caf2mgo slag. Int. J. Mater. Res. 2019, 110, 247-252. [CrossRef]

30. Diao, J.; Xie, B.; Wang, Y.; Guo, X. Recovery of phosphorus from dephosphorization slag produced by duplex high phosphorus hot metal refining. ISIJ Int. 2012, 52, 955-959. [CrossRef]

31. Kondratiev, A.; Jak, E. Predicting coal ash slag flow characteristics (viscosity model for the al2o3-cao-'feo'-sio2 system). Fuel 2001, 80, 1989-2000. [CrossRef]

32. Wu, W.; Lin, C.M.; Chen, J.H.; Li, C.C.; Lin, K.H. Detection of Calcium in the Active Oxide. I600903; 1 October 2017. Available online: https://twpat1.tipo.gov.tw/tipotwoc/tipotwkm?!!FR_I600903 (accessed on 11 April 2020).

33. Wang, G.; Wang, Y.H.; Gao, Z.L. Use of steel slag as a granular material: Volume expansion prediction and usability criteria. J. Hazard. Mater. 2010, 184, 555-560. [CrossRef]

34. Waligora, J.; Bulteel, D.; Degrugilliers, P.; Damidot, D.; Potdevin, J.L.; Measson, M. Chemical and mineralogical characterizations of ld converter steel slags: A multi-analytical techniques approach. Mater. Charact. 2010, 61,39-48. [CrossRef]

35. Ortega-Lopez, V.; Manso, J.M.; Cuesta, I.I.; Gonzalez, J.J. The long-term accelerated expansion of various ladle-furnace basic slags and their soil-stabilization applications. Constr. Build. Mater. 2014, 68, 455-464. [CrossRef]

(C) 2020 by the authors. Licensee MDPI, Basel, Switzerland. This article is an open access article distributed under the terms and conditions of the Creative Commons Attribution (CC BY) license (http://creativecommons.org/licenses/by/4.0/). 